\title{
THE OXIDATIVE STATUS IN PATIENTS WITH CHRONIC KIDNEY DISEASE
}

\author{
V. S. VASYLCHENKO ${ }^{1,2 \bowtie}, L$. V. KOROL ${ }^{1}$, \\ O. B. KUCHMENKO', N. M. STEPANOVA ${ }^{1}$
}

\author{
${ }^{1}$ State Institution "Institute of Nephrology of the National Academy \\ of Medical Sciences of Ukraine”, Kyiv; \\ ${ }^{2}$ National University of Kyiv-Mohyla Academy, Ukraine; \\ e-mail: vasylchenkovita@gmail.com
}

Received: 26 March 2020; Accepted: 25 June 2020

An excess of free radicals accompanies the development of renal pathologies and causes numerous concomitant complications and syndromes. The most common of these are cardiometabolic syndromes in patients with chronic kidney disease. Therefore, the purpose of the study was to determine the activity of paraoxonase-1 and myeloperoxidase, which are associated with indicators of high-density lipoproteins content and oxidative stress in the blood of patients with the chronic stage of kidney disease. The activity of the enzymes, thiobarbiturate-active products concentration and transferrin, ceruloplasmin, thiol compounds content were determined in the blood of patients with chronic kidney disease. The oxidative status was shown to be changed. Thus, myeloperoxidase activity, the content of oxidized proteins and the concentration of thiobarbiturate-positive components were increased, while the activity of the antioxidant enzyme paraoxonase-1, the content of transferrin, ceruloplasmin and thiol compounds were decreased. The ratio of myeloperoxidase / paraoxonase-1 activities was progressively increased up to 9-fold, indicating the presence of cardiovascular complications in patients. The data obtained allowed to extend the range of indicators for monitoring the development of cardiometabolic disorders in the progression of chronic kidney disease.

Ke y w or d s: oxidative status, paraoxonase-1, myeloperoxidase, chronic kidney disease.

$\mathrm{O}$ xidative status is a dynamic combination of reactions that are mediated by oxidant and antioxidant systems. There process on the high level of organizing is important for whole-body homeostasis. Kidneys have controlled this aspect of human health. Oxidation and structural rearrangement of enzymes, in particular on the surface of lipoproteins, are the most common accompanying factors that change oxidative status [1]. Accordingly, impaired lipoprotein metabolism occurs simultaneously or may precede chronic kidney disease (CKD). Such established markers of oxidative status changing as the renal specific are known $[1,2]$. The oxidized proteins and transferrin (TR) are most common in healthcare practice. Lipid peroxidation in CKD can also characterize by the formation of thiobarbituric acid reactive products (TBARP). The oxidation of proteins in the composition of high- and low-density lipoproteins (HDL, LDL) a cause of the development of many pathological conditions, in particular, arterial hypertension, which is a common complication in CKD and other pathologies such as diabetes and chronic inflammatory processes [2-4]. The qualitative state of the particles is determined by the functional activity of the multifunctional enzymes. The paraoxonase-1 (PON-1, EC 3.1.8.1) is associated with HDL. The enzyme has hydrolase, arylesterase and lactonase activities. The most important functions of PON-1 are to protect lipoproteins from oxidative modification $[5,6]$.

PON-1 can form an associated complex with myeloperoxidase (MPO, EC 1.11.1.7). MPO is a heme-containing enzyme which is located in azurophilic neutrophil granules. It is released upon cell

(C) 2020 Vasylchenko V. S. et al. This is an open-access article distributed under the terms of the Creative Commons Attribution License, which permits unrestricted use, distribution, and reproduction in any medium, provided the original author and source are credited. 
activation by external factors or internal mediators and attaches to HDL fractions. Both enzymes partially inhibit each other, reducing their affinity for high-density lipoprotein particles. In addition to lowand high-density lipoprotein modifications, MPO reduces the bioavailability of nitric oxide by attaching chlorine radicals to nitric oxide synthase, arginine, or directly oxidizing it [7].

Peroxidase activity is increased by infectious and inflammatory processes, which in turn induces the processes of free radical lipid oxidation and the appearance of reactive oxygen species [8].

Currently, there is no unified list of prognostic markers of renal disease, therefore, the study of potential indicators of CKD is necessary and important for their prevention and avoidance of secondary complications. Therefore, our research aimed to investigate oxidative status, which includes indicators of the qualitative status of lipoproteins and the index of oxidative status in patients with CKD.

\section{Materials and Methods}

The venous blood samples were taken from 105 patients (42 women and 63 men, age - 18-55 years) with CKD I- V stage (glomerulonephritis). The glomerular filtration rate was calculated using the CKD EPI formula (KDIGO 2012).

When conducting clinical diagnostic and treatment measures, they relied on diagnostic protocols approved by the orders of the Ministry of Health and the National Academy of Medical Sciences of Ukraine, on the recommendations of KDOQI and KDIGO on the diagnosis and treatment of CKD. All patients were divided into three groups: group 1 amounted to patients with CKD I-II stage $(n=35)$; group 2 formed patients with CKD III-IV stage $(n=30)$; group 3 - patients with V stage CKD $(n=40)$. The control group consisted of 30 healthy persons of the same age. All participants gave informed consent for the study before the procedure of obtaining their blood. The study protocol (No 7 30.08.2016) was approved by the Commission on Bioethics of SI Institution of Nephrology NAMS.

Preparation of biological material. Blood from the cubital vein without anticoagulant had been centrifuged for $15 \mathrm{~min}$ at $1500 \mathrm{~g}$ and treated with serum.

Materials and reagents. Phenylacetate, ethylenediaminetetraacetic acid (EDTA), 3,3-dimethoxybenzidine (97\%), 4-(aminobenzoyl)hydrazide (95\%) (Sigma-Aldrich, USA), tris(hydroxymethyl) aminomethane, tris(hydroxymethyl)aminomethane hydrochloride, malonaldehyde bis(diethyl acetal), 1.4-phenylenediamine dihydrochloride, human $\mathrm{CP}$ solution, sodium fluoride, ferric ammonium citrate, potassium iodide were obtained from Sigma-Aldrich (USA). Trichloroacetic acid, thiobarbituric acid, and sodium acetate were received from Merck (Germany). Calcium chloride, sodium hydrogen phosphate, hydrochloric acid, potassium chloride, acetic acid, iodine solution, sodium phosphate monosubstituted, bi-substituted and starch were obtained from HLR (Ukraine). Transferrin was received from BioChemica (Fluka).

Activity of enzymes. The activity of PON-1 is determined by the amount of substrate (phenylacetate) used during the biochemical interaction, which is measured at a wavelength of $270 \mathrm{~nm}$. The samples were diluted with the working solution before identification. The working solution contained the $20 \mathrm{mM}$ Tris- $\mathrm{HCl}$ buffer ( $\mathrm{pH} \mathrm{8.0)}$ ) and $4 \mathrm{mM}$ phenylacetate. The absorption was expressed in $\mathrm{kU} / 1$ [9].

The activity of MPO is determined by the oxidation of chromogenic substrate 3.3'-dimethoxybenzidine $(3.8 \mathrm{mM})$ during the biochemical interaction, which is measured at a wavelength of $460 \mathrm{~nm}$ during $8 \mathrm{~min}$ at $23^{\circ} \mathrm{C}$. The samples were diluted with the working solution before identification. The working solution contained the $0,2 \mathrm{M} \mathrm{Na}_{2} \mathrm{HPO}_{4}$ buffer ( $\mathrm{pH} \mathrm{4.5)}$ and $380 \mathrm{mM} \mathrm{3,3-dimethoxybenzi-}$ dine. In control samples, 4-(aminobenzoyl)hydrazide $(50 \mathrm{mM})$ was additionally added as an inhibitor of MPO. The reaction was started by adding the substrate (peroxide) in a concentration of $100 \mu \mathrm{M}$. The absorption was expressed in mU/l [10].

Defining the index of oxidative status. The content of the protein carbonyl groups (PCG) in serum blood was determined by the reaction of the oxidized amino acid residues of $0.1 \mathrm{M}$ 2,4-dinitro phenyl-hydrazine at $363 \mathrm{~nm}$ and PCG concentration was expressed as $\mu \mathrm{mol} / \mathrm{l}[2]$.

The concentration of SH-groups. The $0.05 \mathrm{ml}$ of serum was dissolved to $0.5 \mathrm{ml}$ with distilled water and added $0.5 \mathrm{ml}$ of $6 \mathrm{M}$ potassium iodide solution, 2 drops of $5 \%$ starch solution and $1.8 \mathrm{ml}$ of $0.1 \mathrm{M}$ phosphate buffer ( $\mathrm{pH}$ 7.6). The absorbance was measured by spectrophotometer KFK-3-01 (ZOMZ, Russia) at $500 \mathrm{~nm}$ before and after the application of $0.3 \mathrm{ml} 0.001 \mathrm{~N}$ of iodine solution. The SH-groups concentration was expressed as $\mathrm{mmol} / \mathrm{l}$ [2].

TBARP concentration. The $0.1 \mathrm{ml}$ serum was added to $1.5 \mathrm{ml} 0.025 \mathrm{M}$ Tris-buffer with potassium chloride ( $\mathrm{pH}$ 7.4). These samples were incubated for 
$30 \mathrm{~min}$ at $37^{\circ} \mathrm{C} ; 1 \mathrm{ml} 20 \%$ solution of trichloroacetic acid was added and centrifuged for $15 \mathrm{~min}$ at $3000 \mathrm{~g}$. Supernatants $(2 \mathrm{ml})$ were added to $1 \mathrm{ml}$ of $0.8 \%$ solution of thiobarbituric acid and heated for $10 \mathrm{~min}$ at $100^{\circ} \mathrm{C}$. The absorption was measured using a spectrophotometer at $532 \mathrm{~nm}$ and TBARP concentration was expressed as $\mu \mathrm{mol} / \mathrm{l}[2]$.

$T R$ concentration. The $0.2 \mathrm{ml}$ of serum was added to $2 \mathrm{ml}$ of $0.2 \%$ solution of ammonium-iron (III)-citrate ( $\mathrm{pH}$ 5.5-5.8). TR concentration was calculated as the difference between the absorbance of the solution for 1 and 30 min, which was measured using a spectrophotometer at $440 \mathrm{~nm}$ [2]. The human TR was used as a standard. The result is expressed in $\mathrm{g} / \mathrm{l}$.

CP concentration. The experienced samples included $0.05 \mathrm{ml}$ of serum, $4 \mathrm{ml} 0.4 \mathrm{M}$ of acetic buffer solution (pH 5.5) and $0.5 \mathrm{ml} 0.5 \%$ aqueous solution of 1,4-phenylenediamine dihydrochloride. The control sample had the same quantity of reagent and biological materials but added additionally the $1 \mathrm{ml}$ of $3 \%$ solution of sodium fluoride. All samples were incubated for 1 hour at $37^{\circ} \mathrm{C}$ after it to the experiment sample was added $1 \mathrm{ml}$ of $3 \%$ solution of sodium fluoride. The absorbance was measured by spectrophotometer KFK-3-01 (ZOMZ, Russia) at $530 \mathrm{~nm}$ and CP concentration expressed in g/l [2].

Statistical analysis. The Kolmogorov-Smirnov test for normality distribution and Student's $t$-test, nonparametric (U-test) Mann-Whitney and Pearson's rank correlation test were used for the statistical analysis. Differences in values were considered statistically significant at $P<0.05$. The result expressed as the mean and standard deviation of the mean.

\section{Results and Discussion}

The activity of PON-1 and MPO was determined in the blood serum of patients with CKD stage I-V using quantitative methods for determining to characterize the state of lipoprotein $[5,9]$. PON-1 is one of the important enzymes associated with lipoproteins. The conducted research has shown the tendency to decrease of arylesterase activity of PON-1 in the patients with CKD on $49.3 \%$ in the first group, $38.5 \%$ in the second group, $37.2 \%$ in the third group compared with practically healthy persons (Table). The difference is statistically significant between tree groups with control $(P<0.05)$ but between second and third groups is absent which means equal functional capability. These changes may signal about losing antioxidant, antithrombotic, anti-inflammation, and antiatherogenic properties of enzymes as a component of HDL [11].

The pro-oxidant and pro-inflammatory HDL particles were associated with increased odds of the acute coronary syndrome and its manifestations in individuals with CKD at high cardiovascular risk [12].

The antagonist of PON-1 is MPO, which also associated with HDL in some period of there metaboism. The second enzyme takes part in the process of activation of the inflammation reaction $[7,13]$. Its activity increases two fold $s$ in one examined group with the patient on the terminal state of CKD (Table).

The obtained value for CKD is forcing wonder about future using for early diagnosis pathologies. Significantly elevated cardiovascular morbidity related to disturbances in lipoprotein metabolism whose consequences are dyslipidemia and the ac-

Indicators of oxidative stress in patients with chronic kidney disease stage I-V compared with conditionally healthy donors $(M \pm m)$

\begin{tabular}{l|c|c|c|c}
\hline \multicolumn{1}{c}{ Indicators } & $\begin{array}{c}\text { Control group, } \\
n=30\end{array}$ & $\begin{array}{c}\text { Patients with CKD } \\
\text { I-II stage, } n=35\end{array}$ & $\begin{array}{c}\text { Patients with CKD } \\
\text { III-IV stage, } n=30\end{array}$ & $\begin{array}{c}\text { Patients with CKD } \\
\text { V stage, } n=40\end{array}$ \\
\hline PCG, $\mu \mathrm{mol} / \mathrm{l}$ & $1.132 \pm 0.182^{\#}$ & $2.085 \pm 0.12^{*}$ & $2.0 \pm 0.14^{*}$ & $2.25 \pm 0.07^{*}$ \\
TBARP, $\mu \mathrm{mol} / \mathrm{l}$ & $128.05 \pm 21.03^{\#}$ & $1157.97 \pm 282.2^{*}$ & $290.58 \pm 53.90^{*}$ & $440.16 \pm 157.7^{*}$ \\
TR, g/l & $5.21 \pm 1.02^{\#}$ & $1.98 \pm 0.46^{*}$ & $2.11 \pm 0.32^{*}$ & $1.84 \pm 0.31^{*}$ \\
CP, g/l & $0.22 \pm 0.01$ & $0.27 \pm 0.04$ & $0.33 \pm 0.06^{*}$ & $0.23 \pm 0.035$ \\
SH-groups, mmol/l & $2.22 \pm 0.02^{\#}$ & $1.60 \pm 0.22^{*}$ & $1.82 \pm 0.16^{*}$ & $1.73 \pm 0.27^{*}$ \\
MPO mU/l & $74 \pm 11^{\#}$ & $109.50 \pm 37.38^{*}$ & $119.88 \pm 34.2^{*}$ & $238.00 \pm 64.58^{*}$ \\
PON-1 kU/l & $5.98 \pm 0.65^{\#}$ & $2.46 \pm 0.79^{*}$ & $3.52 \pm 1.0^{*}$ & $4.09 \pm 1.04^{*}$ \\
\hline
\end{tabular}

$P<0.05$. *Changes are trustworthy compared with a group of practically healthy donors; ${ }^{*}$ changes are trustworthy compared with all groups of patients 
cumulation of atherogenic particles and mortality has been observed in CKD. Cardiovascular diseases are the most frequent cause of death of CKD patients globally. Significantly elevated cardiovascular morbidity and mortality have been observed in CKD [14].

MPO forms a complex with PON-1 in blood circulation. PON-1 inhibits MPO activity by oxidizing tyrosine-71. Consequently, an enzyme is losing affinity with HDL $[6,13]$. The polymorphousnuclear white blood cells release MPO from granules and it can cause oxidative modification of other enzymes and lipoproteins. The substrate for MPO is hydrogen peroxide. It exhibits peroxidase activity and can carry out two-electron oxidation of halogens and pseudohalogens [7]. The oxidized form of nitric oxide, nitric acid chloride can oxidize protein and lipid components of lipoproteins. A nucleophilic group replaces thiocyanate oxidation products. LDLs with such metabolic transformations are captured by macrophages through interaction with class A and $B$ scavenger receptors and are involved in the formation of foam cells [15]. In this case, inactivation of PON-1 in person who has a kidney disease may promote atherogenesis and evoke secondary cardiovascular events [3, 16].

The quantitative methods for determining are allowing revealing the level of functionally active forms of MPO. A lot of diseases caused the intensification of proteolytic and peroxide processes quantities of structurally and, as the results, injured proteins are formed $[15,17]$. Oxidative stress is described as an imbalance between antioxidants and pro-oxidants. Increased oxidative stress is not only the cause of such diseases like atherosclerosis or heart failure but also one of the potential contributing factors to aging [15].

MPO activation formed several active forms of oxygen which can damage the macromolecules, lipoproteins, binding to endothelium for strengthening aggravation inside the vessel and activating inflammation [7]. MPO can be conjugated with CP. These complexes may include also LDL. CP was presented as an endogenic inhibitor of bromine and coloring activity of enzymes [18].

The ratio MPO/PON-1 may be used for monitoring of this changing. The index calculated for prediction of development of acute coronary syndrome in patients with CKD of different stages [19]. The ratio MPO/PON-1 soared 4.7 fold in patients with $\mathrm{V}$ stage, 2.7 fold in patients with III-IV stage and 2 fold in patients with I stage of CKD in contrast with prac- tically healthy donors (Fig.). Significant increasing of ratio MPO/PON-1 in all groups with CDK signals about a lot of peroxidation reactions, especially at the first group which can be caused by the initialization of the pathological process. Nephrology, with adequately tested effective interventions, are developed and population-level risks fall, has the potential to benefit from large streamlined trials similar to those that have led to advances in cardiology. The variety of composite indexes and logical differentiation of peroxidation reaction and reactions with antioxidants can help diagnose the early changing of kidney disease with cardiovascular risk [14, 20].

The arylesterase activity of PON-1 decreases and MPO increases simultaneously with an increase in the content of products of protein peroxidation, in particular, TBARP in the blood serum by $317 \%$, $215 \%$, and $300 \%$, respectively, in patients with the stage I-II, III-IV, and V CKD compared with the group of practically healthy persons (Table). Atamer and research group have similar results in the study as the level of malondialdehyde was significantly higher, while PON-1 activity was lower in CKD than in controls. Consequently, patients with CKD exhibit an oxidant-antioxidant imbalance which is closely related to high levels of atherosclerotic risk factors [4, 21].

Although the inverse relationship between HDL level and risk of ischaemic heart disease was proved by many epidemiological studies, the serum PON-1 may be considered as a new therapeutic target while looking for new antiatherogenic drugs for preventing the complications of atherosclerosis (myocardial infarcts or strokes) [22, 23]. A lot of factors of different genesis influence on evaluating the risk of cardiovascular disease. For example, new research by Zhang and Reilly shows how a highprotein diet increases amino acids in the blood and atherosclerotic plaques. Thus, thereby exacerbating atherosclerotic-plaque build-up in genetically modified mouse models with suppressing mitophagy and increasing apoptosis [24]. CKD is an important public health problem in the world that is why a lot of novel potential serum biomarkers of renal injury are identifying. One research group proposes the heat shock protein as potential biomarkers for CKD as confirming a lot of factors of each form of kidney disease [24-26].

The TR binds to iron and transports it all over the body. Decreased level of this protein can signal about iron deficiency anemia for a different group 


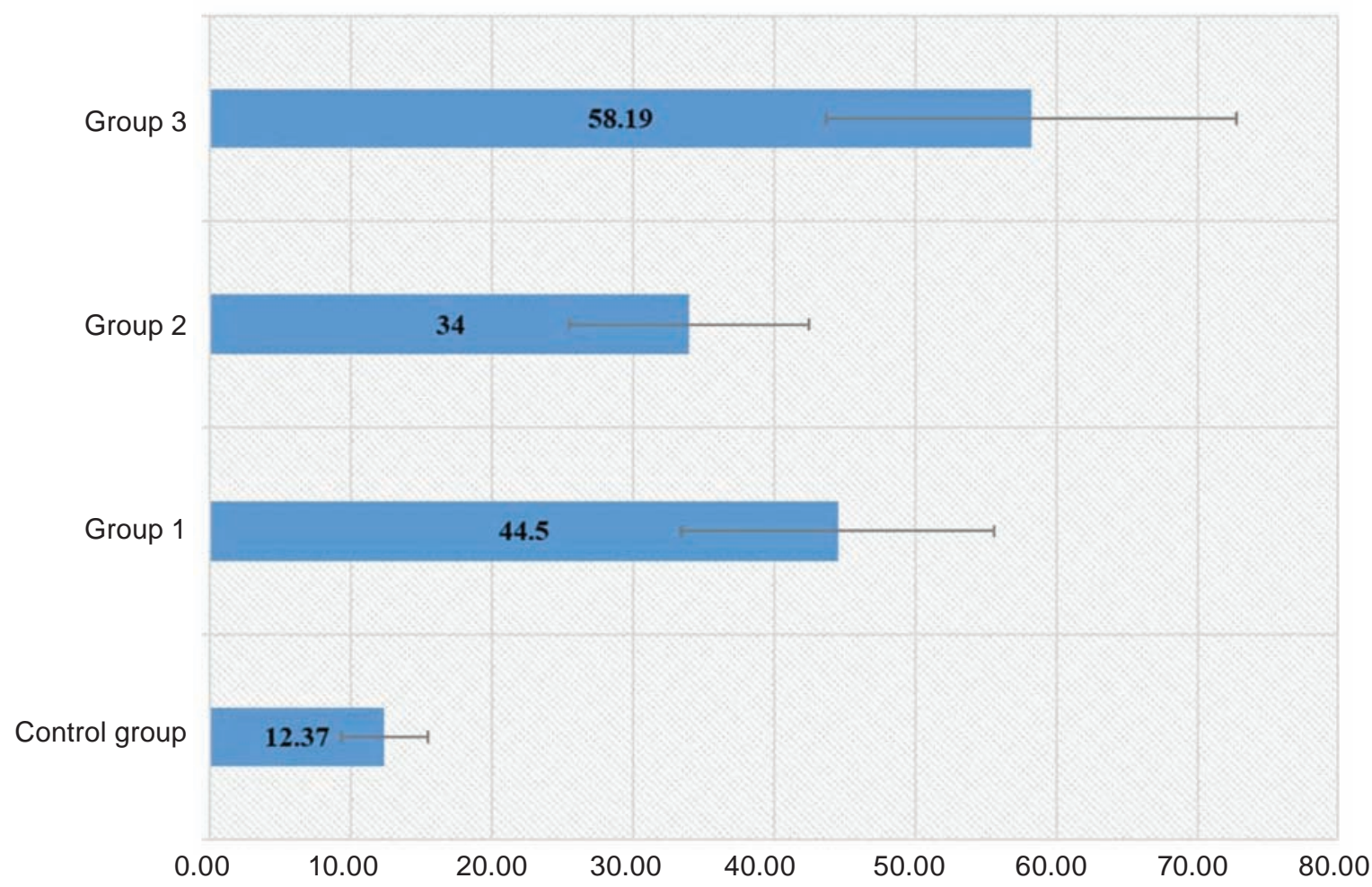

The ratio MPO/PON-1 in conditionally healthy donors (control group) and patients with CKD I-II stage (group 1), patients with CKD III-IV stage (group 2), patients with CKD V stage (group 3)

of disease, especially which conducted with kidney [27]. The prevalence of iron deficiency is often detected in patients with CKD. TR was decreased in the observed groups and measured as $34.7,42.8$, and $68.2 \%$ respectively from meaning in the control group (Table). The receptor to transport protein is overexpressed on the surface of many cancer cells and its level in urine has also been related to a specific kidney disease of Henoch-Schönlein purpura nephritis . The formation of reactive forms of oxygen species from transported ions by TR can play in this process a crucial role [28].

Thiol compounds are the natural reservoir of the reductive capacity of the cells [29]. Chronic renal failure and CKD are accompanied by disturbances in the redox status of plasma thiols [30]. The results showed that the SH-groups in the blood of patients with CKD I-V stages decreased almost two fold compared to conventionally healthy subjects (Table). Data are predicted the expressed activation of the processes of free-radical oxidation of protein molecules in patients that would be increased of carbonyl products of free-radical oxidation of proteins in the blood serum.
To sum up, oxidative status has changed in a patient with CKD. Enzymes, which contained with HDL, have changed their activity: PON-1 has decreased and, in contrast, MPO has increased on the terminal stage. The ratio MPO/PON-1 was increased up to 9-fold and signal about the risk of development of acute coronary syndrome in such patients. A statistically significant damaging of oxidant/ antioxidant balance in the blood serum (increased content of TBARP and decrease SH-groups) were characteristic of the patients with CKD stages I-V. TR significant decrease was recorded in all investigated groups which flagged about lesion of compensatory mechanism compared with healthy donors. Analyzed indicators are expanding the spectrum of indexes for monitoring and studying the early stage of the kidney`s pathological process.

Conflict of interest. Authors have completed the Unified Conflicts of Interest form at http://ukrbiochemjournal.org/wp-content/uploads/2018/12/ coi_disclosure.pdf and declare no conflict of interest. 
The research was conducted within two scientific topics under the numbers of state registration 0119 U000002 and 0117U002122.

\section{ОКСИДАТИВНИЙ СТАТУС У ПАЦІЄНТІВ ІЗ ХРОНІЧНОЮ ХВОРОБОЮ НИРОК}

\section{В. С. Васильченко ${ }^{1,2 \unrhd}$, Л. В. Король ${ }^{1}$, О. Б. Кучменко ${ }^{2}$, Н. М. Степанова ${ }^{1}$}

$$
\begin{aligned}
& { }^{1} Д У \text { «Інститут нефрології Національної } \\
& \text { академії медичних наук України», Київ; } \\
& { }^{2} \text { Національний університет «Києво- } \\
& \text { Могилянська академія», Україна; } \\
& \text { 凶e-mail: vasylchenkovita@gmail.com }
\end{aligned}
$$

Надлишок вільних радикалів супроводжує розвиток ниркових патологій та зумовлює численні супутні ускладнення і синдроми. Найпоширенішими з них $є$ кардіометаболічні синдроми в пацієнтів із хронічною хворобою нирок. Тому метою дослідження було встановлення активності параоксонази-1 та мієлопероксидази, які пов'язані з ліпопротеїнами високої густини, та показників оксидативного стресу в крові пацієнтів із хронічною хворобою нирок I-V стадій. У всіх пацієнтів із хронічною хворобою нирок визначали активність ензимів, концентрацію тіобарбітуратактивних продуктів, вміст трансферину, церулоплазміну, тіолових сполук. Встановлено, що окислювальний статус змінювався: спостерігалося підвищення активності мієлопероксидази, окислених протеїнів та концентрації тіобарбітуратпозитивних компонентів. У той самий час показано зниження в крові активності параоксонази-1, вмісту трансферину, церулоплазміну та тіолових сполук. Співвідношення мієлопероксидази/параоксонази-1 прогресивно збільшувалося до 9 разів, що свідчить про наявність серцево-судинних ускладнень у таких пацієнтів. Одержані дані розширюють спектр показників для моніторингу кардіометаболічних порущень у разі прогресування хронічної хвороби нирок.

К л ю ч о в і с лов в: оксидативний статус, параоксоназа-1, мієлопероксидаза, хронічна хвороба нирок.

\section{References}

1. Dincer N, Dagel T, Afsar B, Covic A, Ortiz A, Kanbay M. The effect of chronic kidney disease on lipid metabolism. Int Urol Nephrol. 2019; 51(2): 265-277.

2. Korol LV, Mygal LYa, Stepanova NM. Intensity of oxidative stress and activity of angiotensin converting enzyme in blood of patients with uncomplicated pyelonephritis. Ukr Biochem $J$. 2017; 89(2): 99-105.

3. Rysz J, Gluba-Brzózka A, Rysz-Górzyńska M, Franczyk B. The role and function of HDL in patients with chronic kidney disease and the risk of cardiovascular disease. Int J Mol Sci. 2020; 21(2): 601.

4. Atamer A, Kocyigit Y, Ecder SA, Selek S, Ilhan N, Ecder T, Atamer Y. Effect of oxidative stress on antioxidant enzyme activities, homocysteine and lipoproteins in chronic kidney disease. $J$ Nephrol. 2008;21(6):924-930.

5. Efe TH, Ertem AG, Altunoglu A, Koseoglu C, Erayman A, Bilgin M, Kurmuş Ö, Aslan T, Bilge M. Serum paraoxonase levels are correlated with impaired aortic functions in patients with chronic kidney disease. Acta Cardiol Sin. 2016; 32(1): 75-80.

6. Kuchmenko O, Mkhitaryan L, Kupchynska O, Ievstratova I, Vasylynchuk N, Matova O, Mostovyak M, Drobotko T. Protein factors of oxidative status and development of pathological state in patients with arterial hypertension. Visnyk Lviv Univ. Ser Biol. 2016; (73): 303-309. (In Ukrainian).

7. Teng N, Maghzal GJ, Talib J, Rashid I, Lau AK, Stocker R. The roles of myeloperoxidase in coronary artery disease and its potential implication in plaque rupture. Redox Rep. 2017; 22(2): 51-73.

8. Murakami T, Okamoto H, Kim H. Structural and functional changes in high-density lipoprotein induced by chemical modification. Biomater Sci. 2015; 3(5): 712-715.

9. Manolescu BN, Berteanu M, Cintezã D. Effect of the nutritional supplement ALAnerv ${ }^{\circledR}$ on the serum PON1 activity in post-acute stroke patients. Pharmacol Rep. 2013; 65(3): 743-750. 
10. Gorudko IV, Cherkalina OS, Sokolov AV, Pulina MO, Zakharova ET, Vasil'e VB, Cherenkevich SN, Panasenko OM. New approaches to the measurement of the concentration and peroxidase activity of myeloperoxidase in human blood plasma. Bioorg Khim. 2009; 35(5): 629-639. (In Russian).

11. Saeed SA, Elsharkawy M, Elsaeed K, Fooda O. Paraoxonase-1 (PON1) activity as a risk factor for atherosclerosis in chronic renal failure patients. Hemodial Int. 2008; 12(4): 471-479.

12. Soria-Florido MT, Olga Castañer O, Lassale C, Estruch R, Salas-Salvadó J, MartínezGonzález MÁ, Corella D, Ros E, Arós F, Elosua R, Lapetra J, Fiol M, Alonso-Gómez A, Gómez-Gracia E, Serra-Majem L, Pintó X, Bulló M, Ruiz-Canela M, Sorlí JV, Hernáez Á, Fitó M. Dysfunctional high-density lipoproteins are associated with a greater incidence of acute coronary syndrome in a population at high cardiovascular risk: a nested case-control study. Circulation. 2020; 141(6): 444-453.

13. Zhang H, Reilly MP. Novel mechanistic links between high-protein diets and atherosclerosis. Nat Metab. 2020; 2(1): 7-8.

14. Herrington WG, Staplin N, Haynes R. Kidney disease trials for the $21^{\text {st }}$ century: innovations in design and conduct. Nat Rev Nephrol. 2020; 16(3): 173-185.

15. Weber C, Noels H. Atherosclerosis: current pathogenesis and therapeutic options. Nat Med. 2011; 17(11): 1410-1422.

16. Gugliucci A, Kotani K, Kimura S. Paraoxonase 1 in chronic kidney failure. J Lipids. 2012; 2012: 726048.

17. Daenen K, Andries A, Mekahli D, Van Schepdael A, Jouret F, Bammens B. Oxidative stress in chronic kidney disease. Pediatr Nephrol. 2019; 34(6): 975-991.

18. Sokolov AV, Kostevich VA, Gorbunov NV, Grigorieva DV, Gorudko IV, Vasilyev VB, Panasenko OM. A link between active myeloperoxidase and chlorinated ceruloplasmin in blood plasma of patients with cardiovascular diseases. Med Immunol. 2018; 20(5): 699-710. (In Russian).

19. Yusova OI, Savchuk OV, Grinenko TV, Kuchmenko OB, Mhitaryan LS, Kupchins'ka OH, Yevstratov IN, Matova OO, Vasilinchuk NM, Drobot'ko TF. Determination of plasminogen/plasmin system components and indicators of lipoproteins oxidative modification under arterial hypertension. Ukr Biochem $J$. 2018; 90(1): 58-67.

20. Miljkovic M, Stefanovic A, Vekic J, Zeljkovic A, Gojkovic T, Simic-Ogrizovic S, BogavacStanojevic N, Cerne D, Ilic J, Stefanovic I, JelicIvanovic Z, Spasojevic-Kalimanovska V, KoturStevuljevic J. Activity of paraoxonase 1 (PON1) on HDL 2 and HDL 3 subclasses in renal disease. Clin Biochem. 2018; 60: 52-58.

21. Deáková Z, Országhová Z, Andrezálová L, Slezák P, Lehotay J, Muchová J, Bürki C, Ďuračková Z. Influence of oak wood polyphenols on cysteine, homocysteine and glutathione total levels and PON1 activities in human adult volunteers - a pilot study. Gen Physiol Biophys. 2015; 34(1): 73-80.

22. Hammadah M, Kalogeropoulos AP, Georgiopoulou VV, Weber M, Yuping Wu Y, Hazen SL, Butler J, Tang WHW. High-density lipoproteinassociated paraoxonase-1 activity for prediction of adverse outcomes in outpatients with chronic heart failure. Eur J Heart Fail. 2017; 19(6): 748755.

23. Prakash M, Shetty JK, Rao L, Sharma S, Rodrigues A, Prabhu R. Serum paraoxonase activity and protein thiols in chronic renal failure patients. Indian J Nephrol. 2008; 18(1): 13-16.

24. Zhang R, Sung SHP, Feng G, Zhang CJ, Kenry, Tang BZ, Liu B. Aggregation-induced emission probe for specific turn-on quantification of soluble transferrin receptor: an important disease marker for iron deficiency anemia and kidney diseases. Anal Chem. 2018; 90(2): 11541160.

25. Romanova Y, Laikov A, Markelova M, Khadiullina R, Makseev A, Hasanova M, Rizvanov A, Khaiboullina S, Salafutdinov I. Proteomic analysis of human serum from patients with chronic kidney disease. Biomolecules. 2020; 10(2): 257.

26. Krzewicka-Romaniuk E, Siedlecka D, Warpas A, Wójcicka G. Paraoxonase 1 as an important antiatherogenic agent. J Educ Health Sport. 2019; 9(1): 133-143.

27. Besarab A, Coyne DW. Iron supplementation to treat anemia in patients with chronic kidney disease. Nat Rev Nephrol. 2010; 6(12): 699-710.

28. Gao M, Monian P, Quadri N, Ramasamy R, Jiang X. Glutaminolysis and transferrin regulate ferroptosis. Mol Cell. 2015; 59(2): 298-308. 
29. Przemysław W, Piotr K, Grażyna C, Danuta KP, Małgorzata I, Bernadeta M, Małgorzata S, Witold S. Total, free, and protein-bound thiols in plasma of peritoneal dialysis and predialysis patients. Int Urol Nephrol. 2011; 43(4): 12011209.
30. Stepanova N, Korol L, Burdeyna O. Oxidative stress in peritoneal dialysis patients: association with the dialysis adequacy and technique survival. Indian J Nephrol. 2019; 29(5): 309-316. 